\title{
Effects of heparin, histamine, and salmon calcitonin on mouse calvarial bone resorption
}

\author{
A J CRISP, J K WRIGHT, AND B L HAZLEMAN \\ From the Rheumatology Research Unit, Addenbrooke's Hospital, Hills Road, Cambridge
}

SUMMARY A quantitative mouse calvarial bone resorption assay was employed to investigate the effects of the mast cell products, heparin and histamine, and of salmon calcitonin. 'Amorphous' heparin, containing a range of molecular weight fractions, inhibited resorption by $15-20 \%$ at concentrations of $0.75-5.0 \mathrm{mg} / \mathrm{ml}$. A 'defined' heparin species of mol.wt 13500 inhibited or resorption by $14-28 \%$ at $10^{-5}-10^{-4} \mathrm{~mol} / \mathrm{l}$. Histamine inhibited resorption by $19-55 \%$ at $\overrightarrow{\mathrm{N}}$ $10^{-3}-10^{-2} \mathrm{~mol} / \mathrm{l}$. It is proposed that heparin and histamine depress coupled bone resorption and formation and may lead to net loss of bone. Salmon calcitonin inhibited resorption at $\frac{\mathrm{O}}{2}$ concentrations as low as $10 \mathrm{pg} / \mathrm{ml}$. 'Amorphous' (but not 'defined') heparin blunted calcitonin induced inhibition of bone resorption and may derepress osteoclasts.

Key words: mast cells.

Mast cells are increased throughout rheumatoid synovium, pannus, and bone erosions ${ }^{1}$ and are the sole source of endogenous heparin ${ }^{2}$ and the major source of tissue histamine ${ }^{3}$ Chronic administration of exogenous heparin to humans, when used in the treatment of ischaemic heart disease, causes a dose related osteoporosis, ${ }^{4-8}$ and de Swiet et al have recently confirmed that heparin promotes significant bone loss in women treated for thromboembolic disease in pregnancy. ${ }^{9}$ The mechanism of heparin induced bone loss is uncertain. There is some evidence that heparin may stimulate the resorption of devitalised bone particles implanted subcutaneously into rats, ${ }^{10}$ but the weight of present evidence indicates that the effect of heparin is primarily antianabolic rather than catabolic. It inhibited linear growth and new bone formation in cultured neonatal mouse bone ${ }^{11}$ and fracture healing in dogs and rabbits. ${ }^{12}$ Heparin qualitatively inhibited the remodelling of cultured human trabecular bone fragments. ${ }^{13}$ The antiproliferative effect of heparin on bone is compatible with previous reports that it inhibits the division of a number of cell types, but smooth muscle cells most consistently. ${ }^{14-16}$ Preliminary studies have shown that heparin has also impaired the division of cultured isolated human trabecular bone cells. ${ }^{17}$

Histamine binding sites have been recently de-

Accepted for publication 5 November 1985

Correspondence to Dr A J Crisp, Rheumatology Research Unit, Addenbrooke's Hospital, Hills Road, Cambridge CB2 $2 \mathrm{QQ}$. scribed on bovine and human chondrocytes ${ }^{18}$ and on cultured isolated human trabecular bone cells, ${ }^{19}$ but little is known about the effects of histamine on articular tissues. There has been only a single report $\Phi$ of the effect of histamine on bones in organ culture. $\stackrel{2}{\vec{A}}$ Histamine inhibited the uptake of proline and $\frac{0}{3}$ thymidine by cultured neonatal rat bones ${ }^{20}$ which suggests that histamine, like heparin, could inhibit new bone synthesis.

Goldhaber introduced the concept that heparin $\frac{\mathscr{O}}{2}$ may act as a cofactor of hormone action on bone. ${ }^{21}$ He reported that heparin potentiated mouse calva- 3 rial bone resorption mediated by parathyroid hor- 0 mone (PTH), but later authors have been unable $₹$ to confirm this. ${ }^{22}$ Heparin, however, stimulates 0 intracellular cyclic adenosine-5'-monophosphate (AMP) production in cultured isolated human trabecular bone cells, ${ }^{23}$ and this lends some weight to the hypothesis that heparin may modulate the actions of hormones on cells that are themselves $N$ often mediated by intracellular cyclic AMP. N Although heparin was not found to potentiate $\mathrm{PTH}_{0}$ mediated increases in cyclic AMP in human bone cells, heparin inhibited calcitonin mediated rises in $\frac{0}{\Phi}$ cyclic AMP in two cultures. ${ }^{23}$ Endogenous calcito- $\stackrel{\oplus}{\rightarrow}$ nin may have an important role in skeletal preserva- 7 tion by suppressing osteoclastic bone resorption. ${ }^{24}$ If $\vec{O}$ this action were inhibited locally by mast cell $\mathbb{\Omega}$ heparin in intact bone it could be relevant to bone $\frac{}{\Phi}$ loss in the rheumatoid erosion.

No quantitative assay of human bone turnover has 
yet been developed and the mouse calvarial bone resorption assay was therefore chosen to investigate these questions further.

\section{Materials and methods}

The mouse calvarial assay employed closely followed the method of Reynolds. ${ }^{25}$ In each experiment 20-26 one day old outbred TO mice from no more than two litters were injected subcutaneously with $1 \mu \mathrm{Ci}$ of calcium-45 chloride (Amersham International, Amersham). The isotope was prepared in a standard solution of $20 \mu \mathrm{Ci} / \mathrm{ml}$ phosphate buffered saline. Mice were killed when five days old by chloroform anaesthesia and decapitation. The calvarial bones (frontal with parietal bones) were isolated under a dissecting microscope and periosteal tissue preserved. Left and right hemicalvaria were separated and assigned to be paired test and control hemicalvaria. All dissection procedures were performed in a special modification of Biggar's medium (Flow, Irvine) with the addition of Lglutamine $200 \mathrm{mg} / \mathrm{l}$ and sodium bicarbonate 500 $\mathrm{mg} / \mathrm{l}$.

Paired hemicalvaria were then placed in culture in $30 \mathrm{~mm}$ diameter plastic Petri dishes (Sterilin, Teddington) on stainless steel platform grids. The level of medium in the dishes just reached the platform of steel mesh so that bones lay at the interface of gas and liquid phases. In each $30 \mathrm{~mm}$ dish $1.5 \mathrm{ml}$ of medium was used containing: special modification of Biggar's medium, L-glutamine 200 $\mathrm{mg} / \mathrm{l}$, sodium bicarbonate $2.2 \mathrm{~g} / \mathrm{l}, 5 \%$ heat inactivated fetal calf serum, penicillin $100 \mathrm{U} / \mathrm{ml}$, streptomycin $100 \mu \mathrm{g} / \mathrm{ml}$, and amphotericin $2.5 \mu \mathrm{g} / \mathrm{ml}$. Dishes were incubated in a humidified atmosphere of $\mathrm{CO}_{2}$ in air $(1: 19, \mathrm{v} / \mathrm{v})$ at $37^{\circ} \mathrm{C}$ for 18 hours to allow equilibration between the bone tissue calcium concentration and that of the medium. After 18 hours medium was removed and $0.5 \mathrm{ml}$ aliquots stored for later counting. Fresh control media and media with the addition of test substance(s) were added to the pairs of hemicalvaria.

Porcine heparin free from preservative was obtained from two sources: firstly, a crude commercial preparation of 168 United States Pharmacopeia units/mg (Sigma, Poole) that included heparin fractions of varying molecular weights and was possibly contaminated by up to $15 \%$ dermatan sulphate (personal communication, Dr Ian Nieduszynski, University of Lancaster). This preparation is referred to as 'amorphous heparin'. Dr Nieduszynski also kindly provided a fraction of heparin obtained after passage down a Biogel P100 column with $2 \cdot 4$ sulphate ester groups per disaccharide unit. This preparation of mol.wt 13500 was free from der- matan sulphate and is referred to as 'defined heparin'. Histamine dihydrochloride was obtained from Sigma (Poole). Salmon calcitonin (batch number P540; potency $4317 \mathrm{IU} / \mathrm{mg}$ was donated by Armour (Eastbourne). Aliquots prepared in $1 \mathrm{mM}$ acetic acid were lyophilised and stored dehydrated at $2^{\circ} \mathrm{C}$.

Test incubations were maintained for 48 hours, after which $0.5 \mathrm{ml}$ aliquots from each dish were removed and stored for later counting. Bones were dried and then dissolved in $0.5 \mathrm{ml} 90 \%$ formic acid for 72 hours. Scintillation fluid (Ultrafluor, USA) was added to aliquots $(9: 1)$ and each specimen counted. The following results (disintegrations per minute, dpm) were recorded: equilibrative dpm (18 hour incubation); test dpm (48 hour incubation); dissolved bone dpm; and the total dpm (equilibrative + test + dissolved bone). Then the percentage ${ }^{45} \mathrm{Ca}$ release (percentage bone resorption) could be obtained from the equation:

$$
\text { Percentage release }{ }^{45} \mathrm{Ca}=\frac{\text { test } \mathrm{dpm}}{\text { total } \mathrm{dpm}} \times 100
$$

All test conditions and controls were performed on quintuplet or sextuplet pairs. Statistical analysis was by paired $t$ tests of the differences between test and control hemicalvaria. Unpaired $t$ tests were employed when comparisons were made between percentage bone resorption with calcitonin alone and with calcitonin plus heparin.

\section{Results}

EFFECTS OF HEPARIN ON MOUSE CALVARIAL BONERESORPTION

Amorphous heparin (Table 1)

No effect on bone resorption was noted at concentrations of $0 \cdot 1 \mu \mathrm{g} / \mathrm{ml}-0.5 \mathrm{mg} / \mathrm{ml}$. A significant inhibition of bone resorption was recorded at $0.75 \mathrm{mg} / \mathrm{ml}\left(3.75-7.5 \times 10^{-5} \mathrm{~mol} / \mathrm{l}\right)$ and $5 \mathrm{mg} / \mathrm{ml}$ $\left(2 \cdot 5-5 \times 10^{-4} \mathrm{~mol} / \mathrm{l}\right)$. This represents inhibition of $18 \%(p<0.05)$ and $20 \%$ (mean of two experiments: $\mathrm{p}<0.01$ and $<0.02$ ) respectively. A $15 \%$ inhibition was also noted with heparin $1 \mathrm{mg} / \mathrm{ml}$ but this did not reach significance. No difference was observed with heparin $10 \mathrm{mg} / \mathrm{ml}\left(0 \cdot 5-1 \times 10^{-3} \mathrm{~mol} / \mathrm{l}\right)$.

\section{Defined heparin (Table 2)}

No effects on bone resorption were found at $10^{-7}-10^{-6} \mathrm{~mol} / 1$. At $10^{-5} \mathrm{~mol} / 1(0 \cdot 135 \mathrm{mg} / \mathrm{ml})$ a $14 \%$ inhibition of bone resorption was noted $(p<0 \cdot 05)$. At $10^{-4} \mathrm{~mol} / \mathrm{l}(1.35 \mathrm{mg} / \mathrm{ml})$ a $28 \%$ inhibition was observed $(p<0 \cdot 001)$. It is apparent that defined heparin is a more potent inhibitor of bone resorption than amorphous heparin on a weight basis. 
Table 1 Effects of amorphous heparin on mouse calvarial bone resorption*

\begin{tabular}{|c|c|c|c|c|c|}
\hline \multicolumn{4}{|c|}{ Heparin } & \multirow{2}{*}{$\frac{\text { Control }}{\% \text { Release }}$} & \multirow[t]{2}{*}{ p Valuc } \\
\hline \multicolumn{3}{|c|}{ Concentration } & \multirow{2}{*}{$\begin{array}{l}\% \text { Release } \\
{ }^{4}(\mathrm{c} a \\
31 \cdot() 2 \pm 6 \cdot 63\end{array}$} & & \\
\hline & $0 \cdot 1$ & $\mu \mathrm{g} / \mathrm{ml}$ & & $35 \cdot 67 \pm 6 \cdot(13$ & NS \\
\hline & $1 \cdot()$ & $\mu \mathrm{g} / \mathrm{ml}$ & $33 \cdot 13 \pm 3 \cdot 13$ & $32 \cdot 77 \pm 2 \cdot 30$ & NS \\
\hline & $10 \cdot()$ & $\mu \mathrm{g} / \mathrm{ml}$ & $3(1.40 \pm 4.93$ & $31 \cdot 76 \pm 3 \cdot 34$ & NS \\
\hline & $0 \cdot 1$ & $\mathrm{mg} / \mathrm{ml}$ & $31 \cdot 36 \pm 7.98$ & $32 \cdot 79 \pm 4.71$ & NS \\
\hline (a) & 0.5 & $\mathrm{mg} / \mathrm{ml}$ & $22 \cdot 62 \pm 2 \cdot 89$ & $24.32 \pm 8.94$ & NS \\
\hline \multirow[t]{3}{*}{ (b) } & 0.5 & $\mathrm{mg} / \mathrm{ml}$ & $28 \cdot 12 \pm 6 \cdot 78$ & $26 \cdot 91 \pm 5 \cdot 76$ & NS \\
\hline & 0.75 & $\mathrm{mg} / \mathrm{ml}$ & $22 \cdot 98 \pm 8 \cdot 40$ & $27.97 \pm 7.79$ & $<0 .(1) 5$ \\
\hline & $1 \cdot 0$ & $\mathrm{mg} / \mathrm{ml}$ & $23 \cdot 67 \pm 2 \cdot 91$ & $27 \cdot 88 \pm 6 \cdot 35$ & NS \\
\hline & $5 \cdot()$ & $\mathrm{mg} / \mathrm{ml}$ & $21 \cdot 68 \pm 1 \cdot 45$ & $26 \cdot(18 \pm \pm 3 \cdot(00)$ & $<0 \cdot(01$ \\
\hline \multirow{2}{*}{ (b) } & $5 \cdot()$ & $\mathrm{mg} / \mathrm{ml}$ & $13 \cdot 17 \pm 0.74$ & $17 \cdot 18 \pm 2 \cdot 06$ & $<0 \cdot(02$ \\
\hline & $10 \cdot()$ & $\mathrm{mg} / \mathrm{ml}$ & $15.98 \pm 1.103$ & $16 \cdot 42 \pm 3 \cdot 17$ & NS \\
\hline
\end{tabular}

${ }^{*}$ The effects are expressed by the percentage release of ${ }^{45} \mathrm{Ca} \pm \mathrm{SD}$. The data were derived from seven separate experiments on quintuplet or sextuplet specimens.

Table 2 Effects of defined heparin on mouse calvarial bone resorption*

\begin{tabular}{|c|c|c|c|}
\hline \multicolumn{2}{|l|}{ Heparin } & ('ontrol & \multirow[t]{2}{*}{ p Value } \\
\hline $\begin{array}{l}\text { Concentration } \\
\text { (mol/l) }\end{array}$ & $\%$ Release t5 $\mathrm{Ca}$ & $\%$ Release ${ }^{+5} \mathrm{C}$ a & \\
\hline $10^{-7}$ & $3(0 \cdot 6.3 \pm 6 \cdot 01$ & $29 \cdot 36 \pm 7 \cdot 34$ & NS \\
\hline $10^{-6}$ & $28 \cdot 14 \pm 5 \cdot 33$ & $29 \cdot 14 \pm 2 \cdot 65$ & NS \\
\hline $10^{5}$ & $25 \cdot 26 \pm 2 \cdot 17$ & $29.52 \pm 3.35$ & $<0.05$ \\
\hline $10^{-4}$ & $23 \cdot(18 \pm 4 \cdot 76$ & $32 \cdot 12 \pm 5 \cdot 78$ & $<0 .(001$ \\
\hline
\end{tabular}

${ }^{*}$ The effects are expressed by the pereentage release of ${ }^{45} \mathrm{Ca} \pm \mathrm{SD}$. based on quintuplet specimens.

EFFECTS OF HISTAMINE ON MOUSE

CALVARIAL BONE RESORPTION (Table 3)

Histamine dihydrochloride $10^{-4}-10^{-4} \mathrm{~mol} / \mathrm{l}$ had no effect on mouse calvarial bone resorption. Histamine $10^{-3} \mathrm{~mol} / \mathrm{l}$ inhibited bone resorption by $19 \%$ $\left(\mathrm{p}<0 \cdot(01)\right.$ and at $10^{-2} \mathrm{~mol} / \mathrm{l}$ inhibited resorption by $55 \%(\mathrm{p}<0 \cdot(001)$.

EFFECTS OF SALMON CALCITONIN ON MOUSE CAIVARIAL. BONE RESORPTION (Table 4)

Significant inhibition of resorption was achieved by all concentrations of salmon calcitonin in the range $1 \mu \mathrm{g} / \mathrm{ml}$ to $10 \mathrm{pg} / \mathrm{ml}$ :

EFFECTS OF HEPARIN ON THE CAICITONIN MEDIATED INHIBITION OF MOUSE

CAIVARIAL BONE RESORPTION

Amorphous heparin (Fig. 1)

Calcitonin $1 \mu \mathrm{g} / \mathrm{ml}$ alone and calcitonin $1 \mu \mathrm{g} / \mathrm{ml}+$ heparin $0.5 \mathrm{mg} / \mathrm{ml}$ inhibited resorption $60 \%$
Table 3 Effects of histamine on mouse calvarial bone $\frac{\square}{9}$ resorption ${ }^{*}$

\begin{tabular}{|c|c|c|c|}
\hline \multicolumn{2}{|l|}{ Histamine } & \multirow{2}{*}{$\begin{array}{l}\text { Control } \\
\% \text { Release of } \\
\% \text { ca }\end{array}$} & \multirow[t]{2}{*}{ p'alue' } \\
\hline $\begin{array}{l}\text { Concentration } \\
\text { (mol/l) }\end{array}$ & $\begin{array}{l}\% \text { Release of } \\
+\mathrm{Ca}\end{array}$ & & \\
\hline $10^{-11}$ & $25 \cdot 17 \pm 4 \cdot 49$ & $31 \cdot 18 \pm 6 \cdot 43$ & NS \\
\hline $10^{7}$ & $23 \cdot 65 \pm 7 \cdot(15)$ & 20.99 $\pm 3 \cdot 44$ & NS \\
\hline $10^{-6}$ & $27 \cdot 14 \pm 3 \cdot 85$ & $27.91 \pm 3.86$ & NS \\
\hline (a) $10^{5}$ & $22.69 \pm 5.24$ & $26 \cdot 92 \pm 4 \cdot(13)$ & NS \\
\hline (b) $10^{-5}$ & $20 \cdot 20 \pm 5.52$ & $22 \cdot 26 \pm 5 \cdot 89$ & NS \\
\hline $10^{4}$ & $24 \cdot 98 \pm 2.47$ & $24 \cdot 46 \pm 3 \cdot 62$ & NS \\
\hline $10^{3}$ & $22 \cdot 43 \pm 2 \cdot 87$ & $27 \cdot 79 \pm 3 \cdot 47$ & $<() \cdot(0)$ \\
\hline $10^{-2}$ & $11.87 \pm 1.25$ & $26 \cdot 13 \pm 3 \cdot 90$ & $<0 \cdot \cdot(0) 1$ \\
\hline
\end{tabular}

*The effects are expressed by the percentage release of ${ }^{4}(\mathrm{C} a \pm \mathrm{SD}$. of based on quintuplet or sextuplet specimens. The data were derived $G$ from three separate experiments.

Table 4 Effects of salmon calcitonin on mouse calvarial bone resorption*

\begin{tabular}{|c|c|c|c|}
\hline \multicolumn{2}{|l|}{ Calcitonin } & Control & \multirow[t]{2}{*}{ p Value } \\
\hline Concentration & $\%$ Release tica & $\%$ Release tica & \\
\hline $1 \cdot 0 \mu \mathrm{g} / \mathrm{ml}$ & $15 \cdot 38 \pm 2 \cdot 6.5$ & $29 \cdot 41 \pm 0.77$ & $<() \cdot()(0) 1$ \\
\hline $0.5 \mu \mathrm{g} / \mathrm{ml}$ & $15 \cdot 47 \pm 1 \cdot 20$ & 3()$\cdot(1)+2 \cdot 28$ & $<0) \cdot 001$ \\
\hline $0.1 \mu \mathrm{g} / \mathrm{ml}$ & $16 \cdot(03 \pm 2 \cdot(00)$ & $27 \cdot 99 \pm 2 \cdot 11$ & $<() \cdot()() 1$ \\
\hline (a) $10 \cdot 0 \mathrm{ng} / \mathrm{ml}$ & $15 \cdot 26 \pm 2 \cdot 15$ & $27 \cdot 8() \pm 1 \cdot 4.3$ & $<() \cdot()())$ \\
\hline (b) $10.0 \mathrm{ng} / \mathrm{ml}$ & $17 \cdot 21 \pm 1 \cdot 33$ & $35 \cdot 68 \pm 3 \cdot 6.5$ & $<() \cdot(k) 1$ \\
\hline $1.0 \mathrm{ng} / \mathrm{ml}$ & $17 \cdot 68 \pm 2 \cdot 86$ & $33 \cdot 33 \pm 3 \cdot 70$ & $<() \cdot() 1$ \\
\hline $0.1 \mathrm{ng} / \mathrm{ml}$ & $18 \cdot 86 \pm 2 \cdot 19$ & $35.64 \pm 1.95$ & $<0 \cdot()(0) 1$ \\
\hline (b) $0.1 \mathrm{ng} / \mathrm{ml}$ & $13 \cdot 34 \pm 0.86$ & $31 \cdot 10 \pm 3 \cdot 33$ & $<() \cdot() 01$ \\
\hline $10 \cdot 0 \mathrm{pg} / \mathrm{ml}$ & $19 \cdot 17 \pm 2 \cdot 75$ & $31.99 \pm 0.94$ & $<() \cdot()())$ \\
\hline $1 \cdot 0 \mathrm{pg} / \mathrm{ml}$ & $31 \cdot 36 \pm 6 \cdot 56$ & $33 \cdot 62 \pm 7 \cdot 3.3$ & NS \\
\hline $0.1 \mathrm{pg} / \mathrm{ml}$ & $34 \cdot 53 \pm 1 \cdot 77$ & $34 \cdot 14 \pm 3 \cdot 92$ & NS \\
\hline $10 \cdot 0 \mathrm{fg} / \mathrm{ml}$ & $32 \cdot 15 \pm 2 \cdot 76$ & $32 \cdot 26 \pm 4 \cdot 6.3$ & NS \\
\hline
\end{tabular}

*The effects are expressed by the pereentage release of ${ }^{45}(a \pm S D$. These data were derived from four separate experiments on quintuplet specimens.

$(\mathrm{p}<0 \cdot(0) 1)$ and $34 \%(\mathrm{p}<0 \cdot 01)$ respectively (Fig. 1a). 을 The difference in inhibition under these two con- $\mathrm{N}$ ditions was not significant and no modulatory effect 5 of heparin () $.5 \mathrm{mg} / \mathrm{ml}$ could therefore be shown.

Calcitonin $1 \mu \mathrm{g} / \mathrm{ml}$ alone and calcitonin $1 \mu \mathrm{g} / \mathrm{ml}+\mathrm{N}$ heparin $0.75 \mathrm{mg} / \mathrm{ml}$ inhibited resorption $56 \%$ ర $(\mathrm{p}<0.001)$ and $62 \%(\mathrm{p}<0.01)$ respectively (Fig. 1b). The difference was insignificant.

Calcitonin $1 \mu \mathrm{g} / \mathrm{ml}$ alone and calcitonin $1 \mu \mathrm{g} / \mathrm{ml}+\stackrel{\mathscr{O}}{?}$ heparin $1 \mathrm{mg} / \mathrm{ml}$ inhibited resorption $59 \%(p<() \cdot(1) 1)$ and $51 \%(p<0 \cdot(0) 1)$ respectively. This blunting of calcitonin induced inhibition in the presence of heparin $1 \mathrm{mg} / \mathrm{ml}$ was significant at $\mathrm{p}<0 .(0)$ (Fig. lc). $\stackrel{\mathbb{D}}{\varrho}$

Calcitonin $1 \mu \mathrm{g} / \mathrm{ml}$ alone and calcitonin $1 \sigma$ $\mu \mathrm{g} / \mathrm{ml}+$ heparin $5 \mathrm{mg} / \mathrm{ml}$ inhibited resorption $64 \%$ 
$1 \mathbf{a}$

$p<0.001 \quad N S \quad p<0.01$
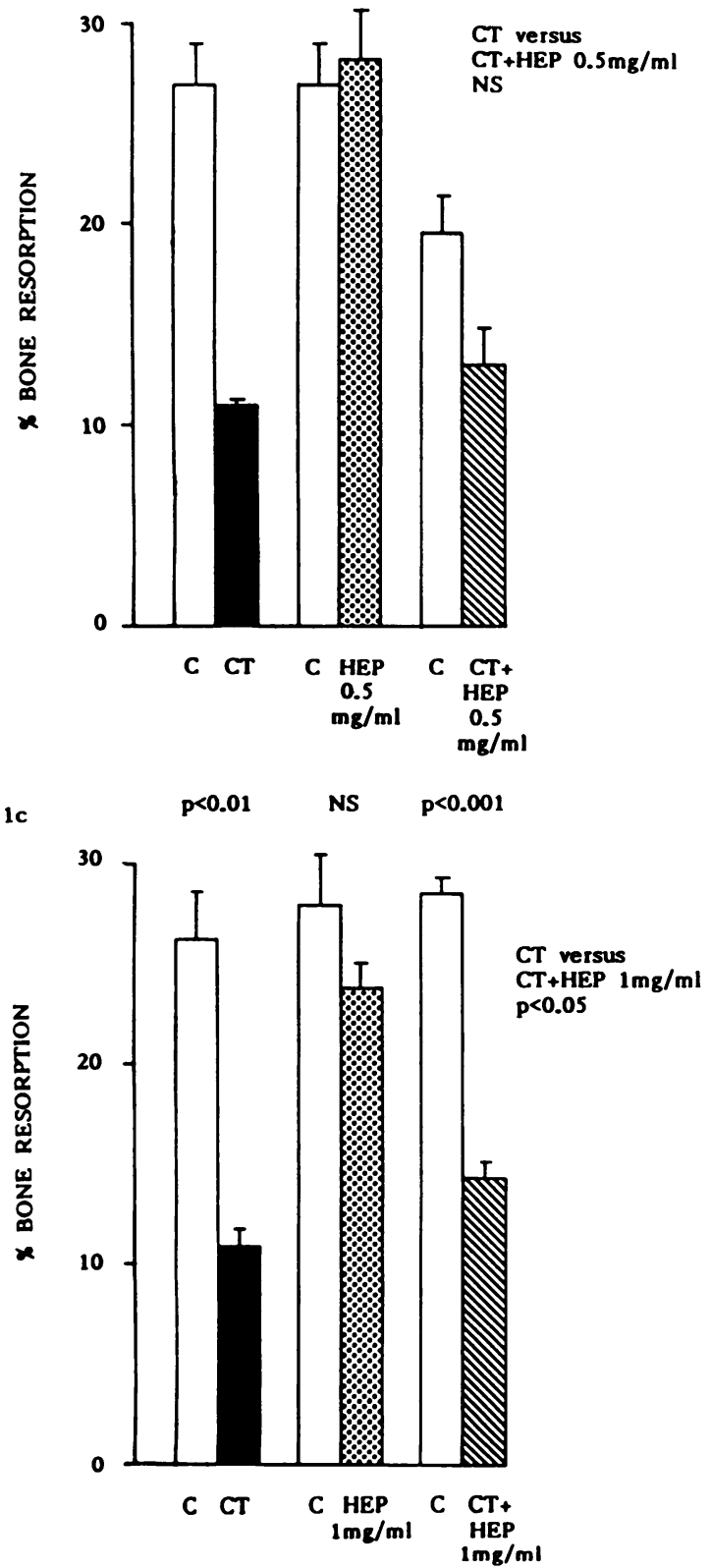

16

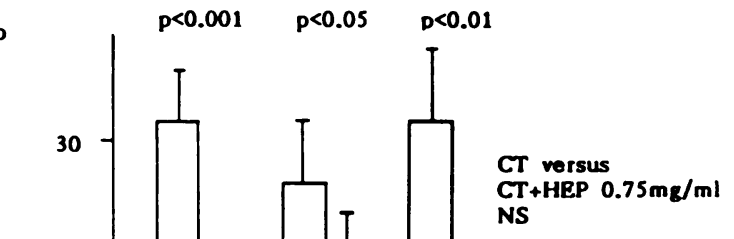

10 $p<0.001 \quad p<0.01 \quad p<0.001$

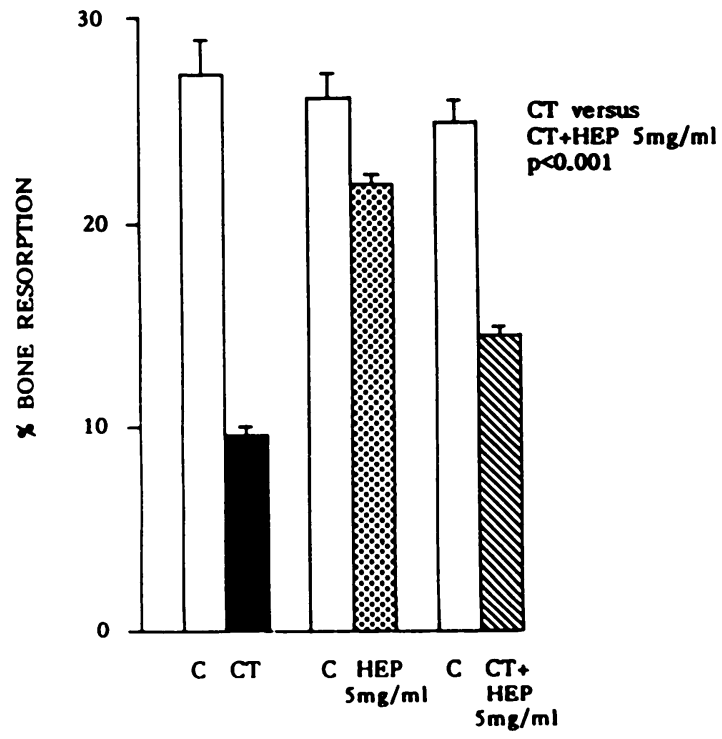

Fig. 1 The effects of salmon calcitonin $1 \mu \mathrm{g} / \mathrm{ml}$ alone $(C T)$, amorphous heparin 0.5-5.0 $\mathrm{mg} / \mathrm{ml}$ alone $(H E P)$, and their combination (CT+HEP) on mouse calvarial resorption are compared with control $(C)$ values. All data are based on quintuplet or sextuplet pairs and results are expressed as means \pm standard errors of means. Significant inhibition of calcitonin induced inhibition of bone resorption was achieved by amorphous heparin 1-5 mg/ml (Figs lc and ld). 
Table 5 Lack of effect of defined heparin on the calcitonin mediated inhibition of mouse calvarial bone resorption*

\begin{tabular}{|c|c|c|c|c|}
\hline $\begin{array}{l}\text { Calcitonin concentration } \\
(\mathrm{pg} / \mathrm{ml})\end{array}$ & $\begin{array}{l}\text { Heparin concentration } \\
(\mathrm{mol} / \mathrm{l})\end{array}$ & $\begin{array}{l}\text { Calcitonin }(+ \text { heparin }) \\
\% \text { release }{ }^{45} \mathrm{Ca}\end{array}$ & $\begin{array}{l}\text { Control \% release } \\
{ }^{45} \mathrm{Ca}\end{array}$ & $p$ Value \\
\hline 100 & - & $13 \cdot 34 \pm 0 \cdot 86$ & $31 \cdot 10 \pm 3 \cdot 33$ & $<0.001$ \\
\hline 100 & $10^{-4}$ & $12 \cdot 60 \pm 0 \cdot 46$ & $33 \cdot 25 \pm 1 \cdot 82$ & $<0.001$ \\
\hline 100 & $10^{-5}$ & $14 \cdot 36 \pm 2 \cdot 65$ & $35.96 \pm 2.98$ & $<0.001$ \\
\hline 100 & $10^{-6}$ & $11.90 \pm 0.68$ & $30 \cdot 85 \pm 3 \cdot 07$ & $<0.001$ \\
\hline
\end{tabular}

${ }^{*}$ Values are expressed as the percentage release of ${ }^{45} \mathrm{Ca} \pm \mathrm{SD}$, based on quintuplet specimens.

$(\mathrm{p}<0.001)$ and $42 \%(\mathrm{p}<0.001)$ respectively. This inhibition of calcitonin induced inhibition of bone resorption was significant at $\mathrm{p}<0.001$ (Fig. 1d).

\section{Defined heparin (Table 5)}

Salmon calcitonin $100 \mathrm{pg} / \mathrm{ml}$ inhibited bone resorption $57 \%(\mathrm{p}<0.001)$ (Table 4$)$. When bones were incubated in salmon calcitonin $100 \mathrm{pg} / \mathrm{ml}$ in the presence of defined heparin $10^{-6}-10^{-4} \mathrm{~mol} / \mathrm{l}$ no modulation of calcitonin induced inhibition was found.

\section{Discussion}

The rheumatoid bone erosion is characterised by active osteoclastic bone resorption of juxta-articular bone. Less attention is paid, however, to the coupled process of new bone formation and attempted repair which occurs on the opposite side of a bone surface undergoing resorption. ${ }^{17}{ }^{26}{ }^{27} \mathrm{By}$ definition, the rheumatoid bone erosion results from net bone loss, but this could follow increased resorption or impaired new bone formation. Exogenous heparin administered to humans causes a dose dependent loss of bone, ${ }^{4-9}$ and most available evidence suggests that heparin acts primarily by inhibition of new bone formation. ${ }^{11-13}$ The present study shows that two preparations of heparin inhibit mouse calvarial bone resorption, but this cannot be simply equated with the conclusion that they depress bone loss. Although experiments showing that heparin inhibits the uptake of proline and thymidine into bone are awaited, it is likely that heparin depresses both of the closely coupled processes of bone resorption and formation and leads to net bone loss. It is of interest that amorphous heparin 10 $\mathrm{mg} / \mathrm{ml}$ exerted no effect on bone resorption. We have shown that amorphous heparin is cytotoxic to cultured human endothelial cells and foreskin fibroblasts at this but not at lower concentrations. ${ }^{17}$ Such high concentrations of heparin may grossly impair the responsiveness of bone cells.

Histamine at $10^{-3}-10^{-2} \mathrm{~mol} / \mathrm{l}$ also inhibited bone resorption and had no cytotoxic effect on cultured human cells. ${ }^{17}$ This finding complements a previous@ report that histamine at concentrations higher than? $30 \mu \mathrm{g} / \mathrm{ml}\left(2 \times 10^{-4} \mathrm{~mol} / \mathrm{l}\right)$ inhibits the uptake of proline and thymidine by cultured neonatal rater bone. ${ }^{20}$ Mast cells are found almost as commonly in proximity to osteoblastic new bone formation as to osteoclastic resorption in the rheumatoid joint, ${ }^{1}$ 17 and it is possible that mast cell degranulation in the $\vec{z}$ joint may promote net bone loss by impairment of the new bone reparative response. It has been estimated that local concentrations of histamine as ${ }_{\infty}^{\circ}$ high as $10^{-3} \mathrm{~mol} / \mathrm{l}$ may be achieved in areas of mast. cell degranulation, ${ }^{28}$ and as heparin exists in approximately 100 times lower molar concentrations than histamine in mast cells, local heparin concen-言 trations of $10^{-5} \mathrm{~mol} / \mathrm{l}$ are conceivable. These phenomena demonstrated in vitro may therefore be $\stackrel{\mathbb{Q}}{\stackrel{\Phi}{ }}$ effective in vivo.

The great potency of salmon calcitonin in the mouse calvarial resorption assay was impressive. It inhibited resorption at concentrations as low as 100 $\mathrm{pg} / \mathrm{ml}$. This must be compared with the known plasma levels of calcitonin in normal 40-70 day old⿳亠丷厂 mice of $93.8 \pm 8.6 \mathrm{pg} / \mathrm{ml}$ using a radioimmunoassayo of human calcitonin. ${ }^{29}$ If the potencies of mouse and salmon calcitonins were similar these data wouldo provide much sought evidence that physiologica $\mathrm{R}$ levels of calcitonin are sufficient to inhibit bone? resorption and protect the skeleton. Since salmons calcitonin is more potent that human calcitonin in humans,${ }^{24}$ this would be an unreasonable assump-r̃ tion. It has been suggested, from findings in two cultures only, that heparin inhibits calcitonin mediated increases of cyclic AMP in isolated humanw trabecular bone cells. ${ }^{23}$ There are precedents for an inhibitory role of heparin on hormone actiono Heparin inhibits luteinising hormone stimulated ovarian adenylate cyclase ${ }^{30}$ and dextran sulphate $\stackrel{\text { ? }}{+}$ the polyanion analogue of heparin, inhibits adenylate cyclase in bovine thyroid preparations. ${ }^{31}$ The present studies of intact mouse bone in orgam culture add some weight to the hypothesis tha $\mathbb{B}$ heparin inhibits the stabilising action of calcitoning on bone. It has been shown that calcitonin and 
heparin both independently inhibit bone resorption, and it might be anticipated that their combined effect on bone resorption would be summatory. In contrast, amorphous heparin $1-5 \mathrm{mg} / \mathrm{ml}$ impaired the calcitonin mediated inhibition of bone resorption. Defined heparin failed to reproduce this effect. It is possible that the amorphous preparation composed of a range of heparin glycosaminoglycans contained the fraction or fractions capable of inhibiting calcitonin, whereas the defined preparation did not. It is conceivable that the dermatan sulphate contamination of the amorphous preparation may also be relevant. Little is known of the properties of the human mast cell heparin released in vivo. A heparin proteoglycan of mol.wt 60000 100000 has been obtained from human lung mast cells ${ }^{32}$ and human skin mastocytoma cells, ${ }^{33}$ but it is unknown whether this represents the sole form of mast cell heparin proteoglycan. Mast cell heparin release adjacent to osteoclasts in the rheumatoid joint could impair the effect of circulating calcitonin and indirectly stimulate osteoclastic resorption. Even if this indirect catabolic effect of heparin can be confirmed, however, it is unlikely to be as important as its primary antianabolic role.

The support of the Arthritis and Rheumatism Council during this study is acknowledged. This work was presented in part at the Provincial Mecting of the British Society for Rheumatology, Manchester, March 1985.

\section{References}

1 Crisp A J, Chapman C M, Kirkham S E, Schiller A L, Krane S M. Articular mastocytosis in rheumatoid arthritis. Arthritis Rheum 1984; 27: 845-51.

2 Straus A H, Nader H B, Dietrich C P. Absence of heparin or heparin-like compounds in mast cell-free tissues and animals. Biochim Biophys Acta 1982; 717: 478-85.

3 Riley J F, West G B. The occurrence of histamine in mast cells. Handbook Exp Pharmacol 1966; 18: 116-35.

4 Griffith G C, Nichols G, Asher J D, Hanagan B. Heparin osteoporosis. JAMA 1965; 193: 91-4.

5 Jaffe M D, Willis P W. Multiple fractures associated with longterm sodium heparin therapy. JAMA 1965; 193: 152-4.

6 Avioli L V. Heparin-induced ostcopenia: an appraisal. $A d v$ Exp Med Biol 1975; 52: 375-87.

7 Sackler J P, Liu L. Heparin-induced ostcoporosis. Br J Radiol 1973; 46: 548-50.

8 Squires J W, Pinch L W. Heparin-induced spinal fractures. JAMA 1979; 241: 2417-8.

9 de Swiet M, Dorrington Ward P. Fidler J, et al. Prolonged heparin therapy in pregnancy causes bone demineralisation. $\mathrm{Br}$ J Obstet Gynaecol 1983; 90: 1129-34.

10 Glowacki J. The effects of heparin and protaminc on resorption of bone particles. Life Sci 1983; 33: 1019-24.

11 Ellis H A. Peart K M. The effects of heparin and dextran sulphate on cultured mouse limb bones. Br J Exp Pathol 1970; 51: $43-52$.
12 Stinchfield F E, Sankaran B, Samilson R. The effect of anticoagulant therapy on bone repair. J Bone Joint Surg 1956; 38A: $270-82$.

13 Crisp A J. Smith D A. Wright J K. Hazleman B L. Darby A J. A histological study of cultured human trabecular bone: effect of heparin and histamine. Br J Rheumatol 1985; 24: 98.

14 Clowes A W, Karnovsky M J. Suppression by heparin of smooth muscle proliferation in injured arteries. Nature 1977; 265: 625-6.

15 Lippman M M, Mathews M B. Heparins: varying effects on cell proliferation in vitro and lack of correlation with anticoagulant activity. Fed Proc 1977: 36: 55-9.

16 Castellot J J, Addonizio M L. Rosenberg R, Karnovsky M J. Cultured endothelial cells produce a heparin-like inhibition of smooth muscle cell growth. J Cell Biol 1981; 90: 372-9.

17 Crisp A J. Mast cells and their products in rheumatoid arthritis. University of Cambridge, 1985. (MD thesis.)

18 Taylor D J. Yoffe J R. Brown D M. Woolley D E. Histamine $\mathrm{H}_{2}$ receptors on chondrocytes derived from human. canine and bovine articular cartilage. Biochem $J$ 1985: 225: 315-9.

19 Crisp A J. Studies of histamine in the rheumatoid joint. Rheumatol Int 1984; 4: 125-8.

20 Norton L A. Proffitt W R. Moore R R. Inhibition of bone growth in vitro by endotoxin: histamine effect. Nature 1969; 221: $469-71$.

21 Goldhaber P. Heparin enhancement of factors stimulating bone resorption in tissue culture. Science 1965; 147: 407-8.

22 Lenaers-Claeys G, Vaes G. Collagenase, procollagenase and bone resorption. Effects of heparin, parathyroid hormone and calcitonin. Biochim Biophys Acta 1979; 584: 375-88.

23 Crisp A J, Roelke M S, Goldring S R, Krane S M. Heparin modulates intracellular cyclic AMP in human trabecular bone cells and adherent rheumatoid synovial cells. Ann Rheum Dis 1984; 43: 628-34.

24 Austin L A. Heath H. Calcitonin: physiology and pathophysiology. N Engl J Med 1981; 304: 269-78.

25 Reynolds J J. Organ cultures of bone: studies on the physiology and pathology of resorption. In: Balls $\mathbf{M}$, Monnickendam M, eds. Organ culture in biomedical research. Cambridge: Cambridge University Press. 1976: 355-66.

26 Collins D H. The pathology of articular and spinal diseases. London: Arnold, 1949.

27 Duncan H, Villanueva A R, Mathews C H, Leisen J C, Parfitt A M. Dynamics of bone destruction and repair in rhcumatoid joints. Arthritis Rheum 1981; 24 (suppl 4): S97.

28 Plaut M. Lichtenstein L M. Histamine and immune responses. In: Gancllin C R, Parsons M E, eds. Pharmacology of histamine receptors. Bristol: Wright, 1982: 392-435.

29 Kent G N, Cohn D V. Blood levels of calcitonin in microphthal$\mathrm{mic}(\mathrm{mi} / \mathrm{mi})$ ostcopetrotic mice cannot account for the resistance of bone to this hormone. Metab Bone Dis Relat Res 1981; 3: 151-3.

30 Salomon Y. Amsterdam A. Heparin: a potent inhibitor of ovarian luteinizing hormone-sensitive adenylate cyclase. FEBS Lett 1977: 83: 263-6.

31 Wolff J, Cook G H. Charge effects in the activation of adenylate cyclase. J Biol Chem 1975; 250: 6897-903.

32 Mctcalfe D D, Lewis R A, Silbert J E, Rosenberg J D, Wasserman S I, Austen K F. Isolation and characterisation of heparin from human lung. J Clin Invest 1979; 64: 1537-43.

33 Metcalfe D D, Soter N A, Wasserman S I, Austen K F. Identification of sulfated mucopolysaccharides including heparin in the lesional skin of a patient with mastocytosis. $J$ Invest Dermatol 1980; 74: 210-5. 